\title{
GAMBARAN KARAKTERISTIK PASIEN KANKER YANG MENJALANI KEMOTERAPI DAN RADIASI DI RUANG KEMOTERAPI SANJIWANI RSUP SANGLAH DENPASAR
}

\author{
${ }^{1}$ Ayudia Rasita Dewi, ${ }^{2}$ Putu Oka Yuli Nurhesti, ${ }^{3}$ Ni Luh Putu Shinta Devi \\ ${ }^{123}$ Program Studi Sarjana Keperawatan Dan Profesi Ners Fakultas Kedokteran Universitas Udayana \\ Alamat Korespondensi: araarasita@gmail.com
}

\begin{abstract}
ABSTRAK
Kemoterapi dan radiasi yang dilakukan secara bersama-sama merupakan salah satu pilihan penatalaksanaan penyakit kanker yang diharapkan dapat mencapai tujuan terapi dengan lebih optimal. Penelitian ini bertujuan untuk mengetahui karakteristik pasien kanker yang menjalani kemoterapi dan radiasi di Ruang Kemoterapi Sanjiwani RSUP Sanglah Denpasar. Penelitian ini merupakan penelitian retrospektif dengan teknik purposive sampling yang menetapkan 53 pasien kanker yang menjalani kemoterapi dan radiasi di Ruang Kemoterapi Sanjiwani RSUP Sanglah Denpasar. Simpulan penelitian ini mayoritas responden berada pada kelompok usia lansia awal (46-55 tahun) sebanyak 18 orang (34\%), berjenis kelamin perempuan sebanyak 40 orang $(75,5 \%)$, dengan jenis kanker yang paling banyak diderita yaitu kanker payudara (52,8\%). Pasien perempuan mayoritas menderit kanker payudara (28 orang), sedangkan pasien laki-laki mayoritas menderita kanker nasofaring (11 orang). Rata-rata responden telah menjalani 5 seri kemoterapi dan 28 seri radiasi. Sebagian besar responden telah menjalani $\leq 5$ seri kemoterapi dan $\leq 34$ seri radiasi. Mayoritas pasien kanker payudara, nasofaring, serviks, dan paru-paru, berurut-turut telah menjalani 4 seri kemoterapi, 4-5 seri kemoterapi, 4-5 seri kemoterapi, serta 5-6 seri. Mayoritas pasien kanker payudara, nasofaring, serviks, dan paru-paru berturut-turut telah menjalani radiasi seri ke-28, radiasi seri ke-32, ke-35, dan ke-37, radiasi seri ke-28, serta radiasi seri ke-29 dan ke36. Peneliti selanjutnya diharapkan dapat melakukan penelitian terkait faktor-faktor yang memengaruhi frekuensi kemoterapi dan radiasi pada pasien yang menderita kanker
\end{abstract}

Kata Kunci: Frekuensi Terapi, Kemoterapi dan Radiasi, Pasien Kanker

\begin{abstract}
Combination of chemotherapy and radiation is one of the options to managing cancer that expected to achieve the goal of therapy more optimally. This study aimed to describe the characteristic of cancer patients undergoing chemotherapy and radiation in Sanjiwani Chemotherapy Room of Central General Sanglah Hospital, Denpasar. This was a retrospective study with purposive sampling method which determined 53 patients as sample. Conclusion of this study shows the majority of the respondents were in early elderly age (46-55 years old) were 18 people (34\%), female were 40 people $(75,5 \%)$. Breast cancer was the common type of cancer in female ( 28 people), whereas nasopharynx cancer was the common type of cancer in male patients (11 people). Average of the respondents had undergone 5 chemotherapy series and 28 radiation series. Majority of the respondents had undergone $\leq 5$ chemotherapy series and $\leq 34$ radiation series. The majority of breast, nasopharynx, cervical, and lung cancer patients consecutively had undergone chemotherapy for 4 series, 4-5 series, 4-5 series, and 5-6 series. The majority of breast, nasopharynx, cervical, and lung cancer patients consecutively had undergone radiation for 28 series, $32^{\text {nd }}$, $35^{\text {th }}$, and $37^{\text {th }}$ series, 28 series, and $29^{\text {th }}$ and $36^{\text {th }}$ radiation series. Future researchers can conduct study related to factors that influence chemotherapy and radiation frequencies in cancer patients.
\end{abstract}

Keywords: Cancer Patients, Chemotherapy and Radiation, Therapy Frequencies 


\section{PENDAHULUAN}

Kanker adalah penyakit yang disebabkan oleh mutasi atau aktivasi abnormal gen seluler yang memengaruhi pertumbuhan dan mitosis sel (Guyton \& Hall, 2016). Penyebaran sel kanker ke jaringan sehat lainnya dapat mengganggu fungsi organ yang jika tidak ditangani dengan baik akan menyebabkan kecacatan dan kematian (Putra, Puspawati, \& Parwata, 2018).

Jumlah penderita kanker meningkat setiap tahunya, secara global diperkirakan terdapat 18,1 juta kasus baru pada tahun 2018 (World Health Organization [WHO], 2018b). Prevalensi penyakit kanker pada penduduk semua umur di Indonesia berdasarkan diagnosis dokter pada tahun 2013 mencapai 1,4\%o atau sekitar 347.792 orang dan meningkat menjadi 1,8\% pada tahun 2018. Jumlah penderita kanker di Provinsi Bali pada tahun 2013 diperkirakan sekitar 8.279 orang (Kementrian Kesehatan Republik Indonesia [Kemenkes RI], 2015; Kemenkes RI, 2018).

Berbagai upaya dilakukan untuk mengatasi jumlah morbiditas dan mortalitas penyakit kanker. Pilihan penatalaksanaan yang ditawarkan berdasarkan pada tujuan pengobatan meliputi penyembuhan penyakit, memperpanjang survival penyakit, atau menghilangkan gejala yang berhubungan dengan kondisi paliatif (Smeltzer et al., 2010). Penatalaksanan penyakit kanker dapat dilakukan melalui pembedahan, kemoterapi , radiasi, imunoterapi, dan terapi hormon (King and Robins, 2006; WHO, 2018a).

Pembedahan merupakan piliihan pertama terapi kanker yang bertujuan untuk mendiagnosis, mengklasifikasikan, dan mengambil massa kanker serta mencegah terjadinya komplikasi yang mungkin terjadi (Yarbro, Wujcik, \& Gobel, 2011). Selain pembedahan, kemoterapi juga menjadi pilihan dalam penatalaksanaan kanker. Kemoterapi membunuh sel kanker yang membelah dengan cepat dengan cara merusak sell kanker meskipun telah jauh dari tempat asalnya (Yarbro Wujcik, \& Gobel, 2011). Kemoterapi sering dilakukan secara multimodalitas bersama dengan pembedahan dan/atau radiasi (Airley, 2009). Radiasi juga sebagai penatalaksanaan kanker yang berbertujuan untuk mengontrol tumor yang tidak dapat diangkat melalui pembedahan atau mengalami metastasis nodus lokal (Smeltzer et al., 2010). Namun pada beberapa kondisi, pasien kanker mendapatkan kemoterapi sambil menunggu terapi definitif radiasi (Amin, Wulawardhana, \& Erawati, 2015).

Penelitian Sonia, Arifin, dan Murni (2014), sebagian besar pasien kanker yang menjalani kemoterapi berada pada rentang usia 40-49 tahun. Berdasarkan jenis kelamin, pasien yang menjalani kemoterapi dan/atau radiasi lebih banyak pada perempuan dibandingkan laki-laki (Sonia, Arifin, \& Murni, 2014; Purwaningsih, Darmono, \& Judiono, 2017). Karakteristik pasien kanker apabila dikelompokkan berdasarkan diagnosa kankernya menurut Sonia, Arifin, dan Murni (2014), pasien yang menjalani kemoterapi paling banyak disebabkan oleh kanker payudara.

Hasil studi pendahuluan yang dilakukan di Ruang Kemoterapi Sanjiwani RSUP Sanglah Denpasar didapatkan bahwa sebanyak enam dari sepuluh pasien kanker di ruangan tersebut mendapatkan lebih dari satu jenis terapi kanker. Sebagian besar pasien kanker di Ruang Kemoterapi Sanjiwani RSUP Sanglah Denpasar menjalani kemoterapi bersama dengan 
radiasi serta telah menjalani lebih dari satu frekuensi terapi.

Namun hingga saat ini belum banyak penelitian yang menggambarkan karakteristik pasien kanker yang menjalani kemoterapi dan radiasi secara bersama-sama yang dapat dijadikan salah satu bahan pertimbangan upaya promotif dan preventif terhadap penyakit kanker. Tujuan penelitian ini yaitu untuk mengetahui gambaran karakteristik pasien kanker yang menjalani kemoterapi dan radiasi di Ruang Kemoterapi Sanjiwani RSUP Sanglah Denpasar.

\section{METODE PENELITIAN}

Jenis penelitian yaitu kuantitatif dengan desain penelitian deskriptif. Rancangn penelitian ini yaitu crosssectional dengan pendekatan restrospective. Peneliti hanya mengumpulkan data mengenai karakteristik pasien kanker melalui data yang tercatat dalam Sistem Informasi Rekam Medis Rumah Sakit (SIMARS) Sanglah.

Populasi penelitian ini yaitu seluruh pasien kanker di Ruang Kemoterapi Sanjiwani RSUP Sanglah Denpasar yang berjumlah 73 orang. Sampel penelitian dipilih menggunakan teknik nonprobability-purposive sampling. Kriteria inklusi penelitian ini yaitu pasien yang menjalani kemoterapi dan radiasi rawat jalan minimal frekuensi yang pertama, pasie dengan usia $\geq 20$ tahun. Kriteria eksklusi penelitian ini yaitu pasien yang data rekam medisnaya tidak lengkap. Sampel yang memenuhi kriteria inklusi dan eksklusi sebanyak 53 orang.

Instrumen penelitian yaitu lembar dokumentas terkait karakteristik demografi responden seperti usia dan jenis kelamin, jenis kanker yang diderita, serta frekuensi kemoterapi dan radiasi yang telah dijalani yang diperoleh melalui SIMARS. Lembar dokumentasi diisi secara langsung oleh peneliti atau asiisten penelitian.

Pengumpulan data dilakukan dengan mengakses Sistem Informasi Rekam Medis Rumah Sakit (SIMARS) Sanglah melalui komputer milik Instalasi Rekam Medis RSUP Sanglah menggunakan username dan password salah satu petugas di Instalasi Rekam Medik. Data yang terkumpul kemudian ditabulasii ke dalam matriks pengmpulan data yang telah dbuat sebelumya oleh peneliti dan kemudian dilakukan analisa data.

Analisis yang digunakan berupa analisis univariat mengacu pada jenis data yang telah dianalisis yaitu usia, jenis kelamin, dan jenis kanker disajikan dalam bentuk distribusi frekuensi, sedangkan data frekuensi kemoterapi dan radiasi dianalisis dan disajikan dalam bentuk tendensi sentral (ukuran pemusatan). 


\section{HASIL PENELITIAN}

Tabel 1 Karakteristik Pasien Kanker yang Menjalani Kemoterapi dan Radiasi berdasarkan Usia dan Jenis Kelamin di Ruang Kemoterapi Sanjiwani RSUP Sanglah Denpasar Bulan Januari-April 2019 $(\mathrm{n}=53)$

\begin{tabular}{cccc}
\hline Variabel & $\begin{array}{c}\text { Frekuensi } \\
(\mathbf{n})\end{array}$ & Persentase (\%) \\
\hline Usia & & \\
& & 2 & 3,8 \\
& Remaja Akhir & 8 & 15,2 \\
& Dewasa Awal & 14 & 26,4 \\
Dewasa Akhir & 18 & 34 \\
Lansia Awal & 11 & 20,8 \\
Lansia Akhir & & \\
& $\mathbf{5 3}$ & $\mathbf{1 0 0}$ \\
\hline Total & 13 & 24,5 \\
\hline Jenis Kelamin & 40 & 75,5 \\
\hline Laki-laki & $\mathbf{5 3}$ & $\mathbf{1 0 0}$ \\
\hline Perempuan & Total &
\end{tabular}

Tabel 1 menunjukkan bahwa mayoritas responden termasuk kedalam usia lansia awal (46-55 tahun) yaitu sebanyak 18 orang (34\%) dan berjenis kelamin perempuan sebanyak 40 orang $(75,5 \%)$.

Tabel 2 Karakteristik Pasien Kanker yang Menjalani Kemoterapi dan Radiasi berdasarkan Jenis Kanker yang Diderita di Ruang Kemoterapi Sanjiwani RSUP Sanglah Denpasar Bulan Januari-April $2019(n=53)$

\begin{tabular}{ccc}
\hline Variabel & Frekuensi (n) & Persentase (\%) \\
\hline Jenis Kanker & & \\
Kanker Payudara & 28 & 52,8 \\
Kanker Nasofaring & 14 & 26,4 \\
Kanker Serviks & 9 & 17 \\
Kanker Paru-paru & 2 & 3,8 \\
\hline Total & $\mathbf{5 3}$ & $\mathbf{1 0 0}$ \\
\hline
\end{tabular}

Tabel 2 menunjukkan bahwa

penyakit kanker payudara yaitu sebagian besar responden memiliki

sebanyak 28 orang $(52,8 \%)$.

Tabel 3 Gambaran Umum Frekuensi Kemoterapi dan Radiasi Pasien Kanker di Ruang Kemoterapi Sanjiwani RSUP Sanglah Denpasar Bulan Januari-April 2019 ( $\mathrm{n}=53$ )

\begin{tabular}{lcc}
\hline \multicolumn{1}{c}{ Variabel } & Median & Min-Max \\
\hline Frekuensi Kemoterapi (seri) & 5 & $2-8$ \\
\hline Frekuensi Radiasi (seri penyinaran) & 28 & $9-37$ \\
\hline
\end{tabular}

Tabel 3 menunjukkan median frekuensi kemoterapi pasien kanker yang menjalani kemoterapi yaitu sebanyak 5 seri. Median frekuensi radiasi pada penelitian ini yaitu 28 seri penyinaran 
Tabel 4 Gambaran Karakteristik Frekuensi Kemoterapi dan Radiasi Pasien Kanker di Ruang Kemoterapi Sanjiwani RSUP Sanglah Denpasar Bulan Januari-April $2019(\mathrm{n}=53)$

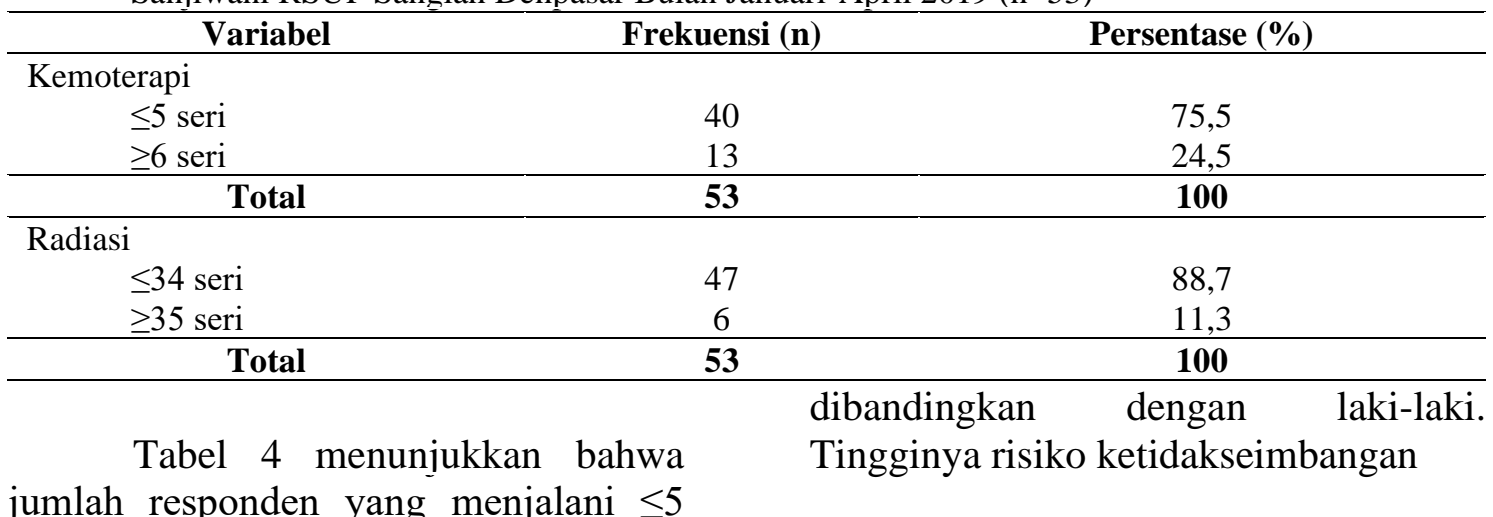
seri kemoterapi sebanyak 40 orang $(75,5 \%)$ dan yang telah menjalani $\geq 6$ seri kemoterapi sebanyak 13 orang $(24,5 \%)$. Jumlah responden yang telah menjalani $\leq 34$ seri radiasi sebanyak 47 orang $(88,7 \%)$ dan yang telah menjalani $\leq 35$ seri penyinaran sebanyak 6 orang $(11,3 \%)$.

\section{PEMBAHASAN}

Rentang usia responden penelitian mulai dari usia 20 hingga 64 tahun. Mayoritas responden dalam penelitian ini termasuk kedalam usia lansia awal. Hasil penelitian ini didukung oleh penelitian Sonia, Arifin, dan Murni (2014) yang menyatakan jika sebagian besar pasien kanker yang menjalani kemoterapi berada pada rentang usia 40-59 tahun. Data Riskesdas tahun 2013, kelompok usia dewasa awal hingga lansia awal (25-54 tahun) lebih berisiko terhadap kanker karena kurangnya konsumsi sayur dan buah, merokok, obesitas, serta sering mengonsumsi makanan berlemak tinggi. Hasil analisis karakteristik responden berdasarkan jenis kelamin pada penelitian ini menunjukkan jika sebagian besar responden berjenis kelamin perempuan. Kemenkes RI tahun 2018, penyakit kanker di Indonesia secara keseluruhan lebih banyak diderita oleh perempuan hormon menyebakan perempuan lebih rentan terkena kanker seperti seperti kanker payudara dan kanker serviks dibandingkan pada laki-laki (Smeltzer et al., 2010).

Hasil penelitian diperoleh data bahwa sebagian besar responden mengalami kanker payudara, disusul dengan kanker nasofaring, kanker serviks, dan kanker paru-paru. Kanker paru-paru dan kanker payudara merupakan dua jenis kanker yang paling banyak diderita dan masuk kedalam lima besar penyebab kematian terbanyak di dunia. (WHO, 2018b). Hal ini sejalan dengan penelitian lainnya yang menyatakan jika pasien yang menjalani kemoterapi maupun radiasi sebagian besar menderita kanker payudara (Sonia, Arifin, \& Murni, 2014; Harfendi \& Yuliasti, 2016). Responden perempuan paling banyak menderita kaker payudara disusul dengan kanker serviks. Sedangkan pada responden laki-laki paling banyak menderita kanker nasofaring dan disusul dengan kanker paru-paru. Hal ini didukung oleh penelitian Harfendi dan Yuliasti (2016) yang menyebutkan jika pasien perempuan dengan kanker yang menjalani radiasi paliatif paling banyak menderita kanker payudara, sedangkan pasien laki-laki menderita kanker 
prostat, nasofaring, dan kanker penis dengan jumlah yang bermbang.

Hasil penelitian diperoleh data jika responden sebagian besar telah menjalani 5 seri kemoterapi dan 28 seri radiasi. Responden paling banyak berada pada kelompok yang telah menjalani $\leq 5$ seri kemoterapi dan yang telah menjalani $\leq 34$ seri penyinaran. Hasil tersebut sejalan dengan penelitian Mustajabah, Setiawan, dan Sudarso (2012) yang menyatakan bahwa pasien dengan kanker nasofaring paling banyak terdapat pada kelompok dengan seri kemoterapi $\leq 5$ siklus dan $\leq 34$ kali penyinaran/radiasi. Banyaknya jumlah terapi dipengaruhi oleh beberapa faktor, yaitu adanya metastase jauh serta stadium kanker yang akan berpengaruh terhadap kepekaan sel kanker terhadap kemoterapi dan radiasi (Priestman, 2012; Mustajabah, Setiawan, dan Sudarso, 2012). Selain faktor yang telah disebutkan diatas, frekuensi kemoterapi dan radiasi yang diterima oleh pasien kanker juga dipengaruhi jenis obat sitotoksik yang digunakan, serta respon yang diberikan oleh tubuh pasien selama menjalani terapi (Unit Promosi Kesehatan RSUP Dr. Sardjito, 2015).

Hasil analisis $\begin{array}{r}\text { frekuensi } \\ \text { kemoterapi berdasarkan }\end{array}$ kanker
payudara pada penelitian $\begin{array}{r}\text { ini } \\ \text { menunjukkan jika sebagan besar }\end{array}$
responden telah menjalani kemoterapi
frekuensi keempat $(28,6 \%)$ Pasien
dengan kanker nasofarng pada
penelitian ini sebagian besar telah
menjalani kemotrapi frekuensi keempat
$(21,4 \%)$ dan kelima (21,4\%). Hasil ini
sejalan dengan penelitian Mustajabah,
Setiawan, dan Sudarso (2012) yang
menyebutkan jika pasien dengan
nasofaring yang menjalani kemoterapi
dan radiasi sebagian besar telah
menjalani kemoterapi $\leq 5$ seri terapii.

Kemoterapi pada pasien dengan kanker serviks diberikan setelah fraksi radiasi diberikan. Guideline menjelaskan bahwa apabila pasien menjalani dua fraksi radiasi maka pasien akan mendapatkan empat seri kemoterapi Cisplatin/5-FU. Hal tersebut sejalan dengan hasil penelitian ini dimana pasien dengan kanker serviks sebagian besar telah menjalani kemoterapi frekuensi keempat $(44,4 \%)$ dan kelima $(44,4 \%)(\mathrm{NCCN}, 2017)$.

Kemoterapi merupakan terapi utama pada pasien dengan kanker paruparu. Pasien yang mendapatkan Carboplatin AUC 6 dan Paclitaxel $100 \mathrm{mg} / \mathrm{m} 2$, kemoterapi akan diberikan pada hari ke-1 setiap 21 hari sebanyak empat seri. Medikasi Carboplatin digunakan apabila pasien tidak mampu mentoleransi Cisplatin (NCCN, 2017). Namun, hasil analisis frekuensi kemoterapi berdasarkan jenis kanker paru-paru pada penelitian ini menunjukkan hasil yang berbeda, yaitu masing-masing responden disebutkan telah menjalani kemoterapi frekuensi seri kelima (50\%) dan keenam (50\%). Adanya sedikit perbedaan antara hasil penelitian ini dengan pedoman terapi yang berlaku diperkirakan dipengaruhi oleh faktor-faktor lain yang tidak dikaji dalam penelitian yang menyebabkan jumlah terapi yang diterima oleh pasien kanker berbeda-beda dan berubah selama perjalanan terapi.

Hasil analisis frekuensi radiasi berdasarkan kanker nasofaring pada penelitian ini yaitu sebagian besar responden telah menjalani radiasi frekuensi ke-32 (14,3\%), ke-35 $(14,3 \%)$, dan ke-37 (14,3\%). Mustajabah, Setiawan, dan Sudarso (2012) pada pasien dengan kanker nasofaring menunjukkan jika responden yang telah menjalani $\leq 34$ kali penyinaran sebanyak 19 orang $(90,4 \%)$ 
Pemberian radiasi pada pasien dengan kanker serviks sedikit berbeda dengan jenis kanker lainnya. Radiasi akan diberikan secara berulang-ulang hingga seluruh sel kanker dinyatakan terbunuh (NCCN, 2018a). Penelitian ini menunjukkan jika pasien dengan kanker serviks sebagian besar telah menjalani radiasi frekuensi ke-28 (33,3\%). Hasil penelitian Astari (2015) menunjukkan jika sebagian besar responden dengan kanker serviks telah menjalani $\geq 12$ seri radiasi, namun tidak disebutkan apakah radiasi yang dijalani merupakan radiasi ulang atau tidak.

Hasil analisis data antara frekuensi radiasi berdasarkan kanker paru-paru pada penelitian ini yaitu responden telah menjalani radiasi frekuensi ke-29 (50\%) dan ke-36 (50\%). Umumnya pasien kanker paru-paru menjalani radiasi selama tujuh minggu atau 30-35 seri terapi (Putra et al., 2015).

\section{SIMPULAN DAN SARAN}

Simpulan peneliitian yaitu sebagian besar responden berada pada usia lansia awal (46-55 tahun) dan berjenis kelamin perempuan, sebagian besar responden memiliki penyakit kanker payudara, sebagian besar perempuan menderita kanker payudara, sedangkan pada laki-laki sebagian besar menderita kanker nasofaring, rata-rata responden telah menjalani 5 seri kemoterapi dan 28 seri radiasi dengan sebagian besar responden telah menjalani $\leq 5$ seri kemoterapi dan $\leq 34$ seri radiasi, pasien kanker dalam penelitian rata-rata menjalani kemoterapi frekuensi keempat sampai kelima, rentang frekuensi radiasi yang dijalani oleh pasien kanker yaitu frekuensi ke-28 sampai ke-37.

Peneliti selanjutnya diharapkan dapat memperluas lingkup penelitian dengan mencari sumber data yang lebih banyak sehingga faktor-faktor yang tidak terkaji dalam penelitian ini seperti stadium kanker, regimen terapi, dan respon terapi dapat dianalisis lebih dalam.

\section{DAFTAR PUSTAKA}

Airley, R. (2009). Cancer chemotherapy: Basic science to the clinic. UK: WileyBlackwell.

Amin, Y., Mulawardhana, P., \& Erawati, D. (2015). Demografi, respon terapi dan survival rate pasien kanker serviks stadium iii-iva yang mendapat kemoterapi dilanjutkan radioterapi. Majalah Obstetri \& Ginekologi, 23(3), 97-105.

Astari, R. Y. K. (2015). Hubungan frekuensi kemoterapi dan kecemasan terhadap asupan energi, protein, lemak dan karbohidrat pada pasien kanker serviks Di RSUD Dr. Moewardi. Doctoral dissertation, Universitas Muhammadiyah Surakarta.

Guyton, A. C., \& Hall, J. E. (2016). Textbook of medical physiology. (13th ed.). United States of America: Elsevier.

Harfendi, G. N., \& Yuliasti, R. (2016). Gambaran Kualitas Hidup Pasien Kanker Stadium Lanjut yang Menjalani Radioterapi Paliatif di RSUD Arifin Achmad Provinsi Riau. Jurnal Online Mahasiswa (JOM) Bidang Kedokteran, 3(2), 1-15.

Kementrian Kesehatan Republik Indonesia. (2013). Riset Kesehatan Dasar (Riskesdas) 2013. Jakarta: Badan Penelitian dan Pengembangan Kesehatan

Kementrian Kesehatan Republik Indonesia. (2015). Pusat data dan informasi kesehatan: Situasi penyakit kanker. Retrieved from: www.depkes.go.id /resources/download/pusdatin/infodatin/i nfodatin-kanker.pdf

Kementrian Kesehatan Republik Indonesia. (2018). Hasil utama riset kesehatan dasar. Retrieved from: http://www.depkes.go.id/resources/downl oad/info-

terkini/materi_rakorpop_2018/Hasil\%20 Riskesdas\%202018.pdf

King, R.J.B,. \& Robins, M.W. (2006). Cancer biology. England: Pearson Education.

Mustajabah, L., Setiawan, D., \& Sudarso, S. (2012). Pola terapi pada pasien kanker 
nasofarinh di RSUD Prof. Dr. Margono Soekarjo. Pharmacy: Jurnal Farmasi Indonesia, 9(02).

National Comprehensive Cancer Network. (2017). Non-small cell lung cancer. Retrieved from: https://www2.trikobe.org/nccn/guideline/lung/english/non _small.pdf. Diakses pada tanggal 5 Juni 2019.

National Comprehensive Cancer Network. (2018a). Cervical cancer. Retrieved from: https://oncolife.com.ua/doc/nccn/Cervical _Cancer.pdf. Diakses pada tanggal 7 Juni 2019.

Priestman, T. (2012). Cancer Chemotherapy in Clinical Practice Second Edition. UK : Springer

Purwaningsih, S., Darmono, S. S., \& Judiono, J. (2017). Pengaruh pemberian diet modifikasi terhadap status gizi pasien kanker dengan kemoradiasi. Medica Hospitalia-Journal Of Clinical Medicine, 2(3).

Putra, Andika Chandra, Fariz Nurwidya, Sita Andarini, Jamal Zaini, Elisna Syahruddin, Ahmad Hudoyo, and Anwar Jusuf. (2015). Masalah kanker paru pada lanjut usia. CDK-234, 42(11), 833-7.

Putra, I. W., Puspawati, N. M., \& Parwata, I. M. (2018). Aktivitas antioksidan senyawa flavooid pada ekstrak n-Butanol daun cendana dan potensinya sebagai agen antikanker dengan metode Brine Shrimp Lethality Test. Cakra Kimia (Indonesian E-Journal of Applied Chemistri), 6(1) 4655.

Smeltzer, S. C., Bare, B., Hinkle, J. L., \& Cheever, K. H. (2010). Brunner \& Suddarth's textbool of medical-surgical nursing (Vol. 1). East Washington Square: Lippincott Williams \& Wilkins.

Sonia, G., Arifin, H., \& Murni, A. W. (2015). Hubungan mekanisme koping dengan kepatuhan kemoterapi pada penderita keganasan yang mengalami ansietas dan depresi. Majalah Kedokteran Andalas, 37(1), 32-37.

Unit Promosi Kesehatan RSUP Dr. Sardjito. (2015). Kemoterapi. Retrieved from: https://www.sardijito.co.id. Diakses pada tanggal 1 Juni 2019

World Health Organization (2018a). Cancer: Diagnosis and treatment. Retrieved from: https://www.who.int/cancer/treatment/en/

World Health Organization. (2018b). Latest global cancer data. International Agency for Research on Cancer, 1-3.
Yarbro, C. H., Wujcik, D., \& Gobel, B. H. (2011). Cancer Nursing: Principle and Practice (7th ed.). United States of America: Jones and Bartlett Publishers. 